\title{
Albanian-Style Laïcité: A Model for a Multi-Religious European Home?
}

\author{
Arolda Elbasani \\ Robert Schuman Center for Advanced Studies, Florence \\ Contact: arolda.elbasani@eui.eu \\ Artan Puto \\ University of Tirana, Albania \\ Contact: artanputo@yahoo.com
}

\begin{abstract}
As a Muslim-majority and multi-denominational polity, Albania has historically searched for suitable institutional solutions to reconcile Islam with a pluralist society, a unitary nation and often fragile European statehood. The post-Communist solutions for the management of this frail plurality are commonly framed within a local tradition of laïcité (Alb. shtet laik), which adapts the French model of separation between state and religion to particular Albanian goals and compromises. Our analysis explores the continuities and changes that mark the Albanian brand of laïcité, with a focus on specific solutions for managing the Islamic majority. The analysis suggests that home-grown interpretations of laïcité capitalize on historical precedents - or traditional solutions - that proved successful in accommodating Islam, religious plurality and European statehood during the founding of the independent Albanian state. Similarly to the past, post-Communist choices insist in safeguarding a local traditional version of Islam, which provides backing for the country's consensual political goals - national unity and European anchorage.
\end{abstract}

Keywords: Islam, Religious Pluralism, State-Church Relations, laïcité, Albania 


\section{Introduction}

This article explores the reconfiguration of state-church relations, focusing on the management of Islam in post-Communist Albania. Considered a European 'anomaly' since its very creation, the country has persistently struggled to balance an odd configuration - an Islamic majority, a pluralist society ${ }^{1}$ and an often-fragile statehood. ${ }^{2}$ Indeed, searching for appropriate solutions that reconcile a pluralist society, a unitary nation and European statehood has represented a permanent challenge for the Albanian polity in the past, just as in the present. The postCommunist solutions for the management of this frail plurality are commonly framed within a local tradition of laïcité, which adapts the French model of strict separation between state and religion to country's specific goals and compromises. ${ }^{3}$ This local-specific adaptation, moreover, is seen as a fundamental choice of European modernity, which conjoins the past and the present. As former President Bamir Topi explains, 'Laïcité is a phenomenon marking the passage to [European] modernity and Albania was founded as such. The state will keep up with this outstanding tradition [] because laïcité ensures both religious freedoms and co-existence of plural interests in a democratic society'.

The term laik state and/or tradition, however, is often taken at face value in terms of its resemblance to the French model, the resolute choice for modernity, and the obstinate continuity across different regimes and moments of transition. Our analysis explores the continuities and changes that mark the Albanian brand of laïcité, with a focus on specific arrangements to manage the Islamic majority after the collapse of Communism. Although the analysis necessarily delves into the broader redefinition of the state's relations with all the religious communities, the main unit of analysis is the Albanian Muslim Community (AMC). ${ }^{5}$ The underlying questions of the article are: what are the emerging institutional devices to manage the Islamic community? How have they developed and changed during different political regimes and socio-political circumstances? To what extent do contemporary choices replicate historical precedents in accommodating religious rights in a multi-religious society striving to assert its Europeanness? 
We are particularly interested in exploring the local institutional arrangements, involving the rights and restrictions upon Muslims' activities, from a bottom-up perspective that is sensitive to relevant actors' preferences and specific contingencies of time and place. The aim is to go beyond formal devices of laïcité, and particularly the French version thereof, by exploring the transformation of the model in the context of Albanian historical trajectory, public debates and political use of the term. To this end, we adopt a comparative historical methodology and use process tracing to analyze how leading intellectuals’ ideas, political strategies and historicallyembedded templates inform the management of Islam in the post-Communist era. ${ }^{6}$ Such a methodology is not only more attuned to capturing the complexity of institutional development, but it also enables us to move back and forth between conceptual definitions and empirical data, promising new venues for empirical validation of contingent interpretations of secularism in specific socio-political contexts.

The argument proceeds in three sections. Section I explores the founding templates to revising the former privileges of the Muslim community during the creation of the independent Albanian state, in the period from 1913 to 1944. Section II provides a short background concerning the overall destruction of religious life inherited after decades of Communist atheist dictatorship, from 1944 to 1990. Section III, the core analysis, investigates the revised relationship between the state and the Muslim majority after the collapse of Communism.

The analysis suggests that post-Communist interpretations of laïcité in general, and institutional management of Islam in particular, capitalize on historical precedents -traditional solutions- that proved successful in accommodating Islam in a context of religious plurality and European statehood during the creation of the post-Ottoman Albanian state. Similarly to the past, traditional choices involve safeguarding a local reformist version of Islam, which provides backing for the country's general political goals - national unity and European anchorage. The privileges accorded to the formal Sunni hierarchy ultimately distinguish it as the official provider, indeed an institutional transmitter, of the Albanian-specific traditional templates. According to this model, the state holds the reins in terms of enforcing the traditional vision of Islam, maintaining the delicate balance between competing religious visions and advancing a plural understanding of the 'common good'. That the model commands the consensus of a 
powerful coalition of political actors - mainstream intellectuals, political elites and the centralized Sunni establishment - legitimizes and perpetuates Albanian-specific choices of laïcité, and indeed, a model of close state supervision. These findings corroborate a broader research agenda that challenges the doctrine of secularism as a 'global phenomenon', and argues instead that the relations between particular political regimes and religious traditions are locallydependent constructs. ${ }^{7}$ Hence, institutional choices and practices of secularism can only be meaningfully investigated in individual cases and at specific moments in time.

\section{Historical Templates for Creating a Unitary and European Nation-State}

What Albanians often refer to as local tradition is a historical set of institutional and ideological solutions negotiated during the creation of the post-Ottoman independent nation-state, 19131939. This historical pool of choices reflects decisions taken under the specific conditions that marked the foundation of the Albanian state - a tiny Islamic-majority and multi-denominational polity, largely considered a European anomaly at the time. That Albanians were among the last people of the empire to mature into a national movement and achieve independence; were surrounded by Orthodox-majority entities claiming their territories; and were internally scattered along competing regional and religious loyalties did not help convince Europeans otherwise. To most outsiders, the distinction between an Albanian Muslim and a Turk was at best blurred, while the existence of a multi-religious nation seemed a rather vague and certainly not familiar concept. $^{8}$

The London and Paris peace conferences, which aimed to chart the new political borders of former Ottoman territories in 1913 and 1919 respectively, risked identifying Albanian Muslims with the Ottoman Empire, or even worse, Asiatic Turks. The already independent Balkan states, meanwhile, kept drawing and redrawing plans to share the remainder of the Ottoman territories. Possible partition of these territories amongst European Christian allies in the region and/or outright deportation of the contested Muslim population were a permanent threat for the Muslim Albanians. The internal religious divisions among Bektashi, Sunni, Christian Orthodox and Christian Catholic - each with their own preferences, doctrinal teachings and communal 
allegiances - did not bode well for internal cohesion either. ${ }^{9}$ The Albanian national movement thus faced two mounting tasks: firstly, to convince European powers of the existence of a unitary nation worth having its own 'European state'; and secondly, to actually unify scattered communities towards a common national imaginary. These challenges hung over every major decision that shaped local solutions for planning and engineering the aspiring nation-state.

\section{Intellectual Projections}

The canonical writings of the Albanian National Renaissance Ideologues (Alb. rilindasit) first sketched what were to be the specific features of the imagined nation-state: areligious, unitary, and European. Writing in the context of the collapse of the Ottoman Empire and well-attuned to European geopolitics, renaissance activists were aware that the existence of a Muslim majority and multiple denominations deprived the Albanians of the essential prerequisites for recognition as a European nation. To convince Europeans that Albanians indeed constituted a unitary and historically distinct polity, they proposed to forge internal homogeneity, on the one hand, and emphasize the country's ancient European roots, on the other. ${ }^{10}$ Related proposals tackled head on the religious 'problem', including both the issue of religious divisions and the provenance and future of the contested Muslim majority.

Regarding internal homogeneity, national ideologues propagated a kind of 'civil religion' or 'Albanianism', which essentially downplayed the divisive role of religion and advocated for new arrangements that placed religious communities at the service of national unity. The new approach to religion was epitomized in Vasa's much quoted verses: 'let us, as brothers, swear an oath, not to mind church or mosque, the faith of Albanians is Albanianism.' The concern with homogeneity was certainly a central and reoccurring theme of Albanian renaissance ideology, but gained fervour during specific historical moments when the very existence of the polity came under threat. During the annexation of Kosovo by the Serbs in 1912, for example, another poet, Asdreni, summoned his patriots 'to end their religious quarrels and unite in order to save what

remained of the country. ${ }^{11}$ As a prominent representative of the renaissance movement bluntly put it, to the 'real' Albanian 'his brothers are his co-nationals, not his co-religionists'. ${ }^{12}$ 
Regarding the provenance and destiny of the Albanian Muslims, renaissance activists mobilized to gather 'scientific' proof that they were 'white Europeans', who hailed from 'an ancient European Pelasgian-Illyrian race' and not the feared 'Asiatic Turks'. ${ }^{13}$ In this line of argument, Albanians were further distinguished from Turks by depicting the latter as 'brutal', 'despotic', 'uncivilized', 'barbaric' and 'backward', all features associated with the dark 'Orient'. ${ }^{14}$ Europe, instead, was depicted as the Albanians' natural home, which represented the 'true faith' and 'progress' that Albanians had always fought for.

The suggested pillars of areligiosity, national unity, and European provenance ultimately framed an increasingly standard narrative of Albanians' otherwise cluttered historical experiences and common identity. ${ }^{15}$ In addition, the renaissance-era intellectuals proposed concrete institutional solutions to formalize the prescribed narrative of the nation, discipline the uncomfortable Muslim majority and handle religious divisions. Specifically, they advocated the restructuring of divisive religious communities into 'Albanianized' autocephalous national churches. These were to be tutored by a laic state charged with the preservation of the whole nation and its European 'destiny'. 16 The aim was to ensure that religious communities would indeed adhere to the prescribed imaginary of a national 'we-ness'.

\section{The Political Pursuit of Albanianism}

Intellectual templates for construing an independent European nation-state gained ground during the eventful consolidation of Albanian statehood. The relationship between the emerging state authorities and religious constituencies closely followed the suggested Albanianist template cultivation of a supra-religious national consciousness under the ultimate guidance of the state.

Initial reforms were conducted under the tutelage of the European powers, which, doubtful of the Albanians' credentials, nominated a German Protestant prince, Wilhelm von Wied, to prepare the country for independent statehood. The first Statute of Albania, adopted in April 1914 while the country was still under Wied's rule, represented a gradual step to separate the state from religion, and the Ottoman legacy more generally. The statute made sure to differentiate between political and religious authority, and placed religious communities under state control. ${ }^{17}$ 
Religious communities, were still allowed some rudimentary political influence, ${ }^{18}$ but within a system of separation between the state and church. In order to ensure a gradual transformation, the creation of 'Albanianized' autocephalous communities was postponed to a later period. ${ }^{19}$ These initial reforms, however, lasted for only a few months in 1914, and could not achieve much on the ground as the country became a battlefield for competing European armies soon after the start of WWI.

The organization of the 1920 Congress of Lushnja consolidated the power of central state authorities and paved the way for new local impulses towards modern and unitary state building. ${ }^{20}$ Still, the emerging authorities faced the 'sublime' task of carving 'a nation and a state out of a gathering of tribes'. ${ }^{21}$ The 1922 Constitution first established the main contours of the model of secularism, tailored to country's troublesome religious plurality: the state had no official religion; all religions were free; but they were excluded from any role in the system of legal jurisdiction or politics. ${ }^{22}$ In particular, the state’s claim to neutrality targeted the privileges that the Muslim majority enjoyed during the outgoing Empire. The Sunni Organization, the predecessor of the AMC, first founded in 1923, served as the transmitter of the state-led modernist reforms. Under the urge of the state, the organization issued new statutes in compliance with state legislation; severed all the administrative, financial and spiritual links with Sheh-ul-Islam in Istanbul; and centralised religious authority into an easy to control national hierarchy. ${ }^{23}$

Modernization reforms took on new impulses once Ahmet Zogu came into power, first as president, from 1924 to 1928, and later as self-proclaimed king of Albania, from 1928 to 1939. During his reign, Zog embraced the renaissance ideals of unity, areligiosity and European modernity, and turned them into the very ideology of the state. He further added authoritarian might to enforce an Albanian version of laïcité, namely: 1) state neutrality; 2) a plethora of religious rights; and 3) co-optation of religious communities to state's goals. The 1925 Constitution arranged for stricter state controls on the activity of religious groups and expanded the competences of Zog in 'tutoring' religious authorities and 'preventing' them from infringing national 'unity'. Zog's increased powers as king of the country after 1928 allowed him more authority to pressure religious communities into following the state's vision of a 'true European 
state'. ${ }^{24}$ Specifically, the 1928 Statute of the Kingdom tightened state supervision over religious communities and religious education was placed under the control of the Ministry of Education. ${ }^{25}$ A 1929 decree on the administration of religious communities put them under the jurisdiction of the Ministry of Justice, and banned the clergy from pursuing political goals. The king himself took on exceptional powers to replace the chairs of religious communities whenever needed. He also took it upon himself to remind the communities of their national-patriotic tasks: 'Do not forget that while fulfilling the holy duty... the fatherland must be above everything. ${ }^{26}$

Intellectuals in general gave their backing to the state's top-down modernist approach, and argued that Muslims had no other choice but to reform according to 'principles of present European life'. ${ }^{27}$ The central Sunni Organization followed suit, and adopted the template of Albanianism, including its twist towards European modernity and civilizational progress. In line with state-demanded reforms, the Sunnis’ 1929 congress, which was de facto organized by the state, adopted highly controversial reforms, including the use of Albanian as the official language for sermons, the unification of all local madrassas into a single institution, and the closure of many 'superfluous' mosques. ${ }^{28}$ The AMC's reshuffled statutes required its head 'to be faithful to the King, to the fatherland and to respect the Constitution with national consciousness". ${ }^{29}$ The new chair of AMC, moreover, was selected from the rounds of the country's reformist layers. The 1929 Civil Code abolished also remaining competences of the Islamic courts by stripping the Muslim hierarchy of any forms of political and legal authority. ${ }^{30}$ When the country was occupied by the Fascist Italy in 1939, the nationalized Sunni Organization submitted rather easily to the new authorities. Official publications adopted a benevolent stance towards Fascism and denounced anti-Fascist elements as enemies of Islam. ${ }^{31}$ The Sunni hierarchy followed a similar strategy vis-à-vis Nazi occupation. Large-scale reforms to nationalize, modernize and co-opt Muslims into the state's political vision were so powerful that the incumbent foreign authorities had no serious difficulties in subduing the Muslims establishment to their own political agenda.

\section{Atheist Policies and Eradication of Religion}


The subsequent Communist regime, which held power from 1944 to 1990, took on board the main renaissance ideals of national unity and areligiosity, but it recoded them to assault and in fact eradicate the role of religion as a political, social and moral institution. Religion, considered as a tool of 'foreign aggression' but also an obstacle to the education of the rational socialist man, became subject of forceful atheist policies. Regime's repression of religion evolved in progressive stages, each harsher than the previous one.

The initial crackdowns consisted in curtailing religious organizations' financial and organizational autonomy via the land reform and/or a ban on charity services. More intrusive controls on religious education and heavy censorship of all forms of religious communication publications, literature and weekly sermons -followed after Communists' consolidation of power. $^{32}$ Towards the 1950 s, the regime moved to arrest, indict and sentence all 'reactionary' clerics. The main religious establishment was replaced with party cronies. A 1949 decree obliged the clergy to declare loyalty to the Communist Party and to the People’s Republic of Albania. ${ }^{33}$ Academic institutions and state intelligentsias, generously funded by the regime, took an active role in depicting a 'historical' narrative of the clergy as perennial enemies of the nation, foreign agents, and impediments to country’s general social and economic progress.

A 'complete emancipation from religious beliefs', indeed the most deadly assault on religious organizations followed in the 1960s. This phase of anti-religious policies, which was modelled on Mao's Cultural Revolution, ended with the abolition of the right of religious practice and the repeal of all related regulations and laws. ${ }^{34}$ All remaining religious edifices were closed, demolished or transformed for other uses, including as public toilets or sport halls. Clerics were forced to publically denounce their faith, and those who refused were executed or sent to be reeducated in the political camps of the regime. The education system became a crucial chain of the harsh propaganda against religious 'superstitions' and 'backward customs'. The private practice of religion, and even the possession of religious literature, became legal offences subject to several years of criminal punishment. Communist mass organizations, which permeated society at all levels, were instructed to report individuals performing religious rituals, even within the privacy of their homes. The public campaign to adjust religious names in 1975 illustrates how deep the atheist campaign permeated every aspect of individual choices. The 
1976 Constitution became the first document in the world to officially endorse atheism: 'the state supports atheist propaganda for the purpose of inculcating the scientific materialist world outlook, ${ }^{35}$

After the death of the main architect of Communist regime, Enver Hoxha, in 1984, the country adopted more lenient policies towards religion until lifting the ban on religious propaganda in May 1990 and the ban on religious practice a few months later during that year. Liberalization of religious restrictions encouraged the swift commencement of religious practice and the reorganization of religious communities. ${ }^{36}$ The vacuum of institutional regulations and the legacy of destruction, however, were much more difficult to undo.

\section{Revising the Relationship between State and Religion}

\section{The Institutional Vacuum and Booming Islamic Activities}

For most of the 1990s, Albania had no institutional arrangements to regulate the state's relation with the revived religious communities. After decades of Communist repression, political elites and religious communities felt the sole urge to expand and assert the body of religious freedoms. ${ }^{37}$ The first opposition, the Democratic Party (DP), an umbrella organization which represented different strata unhappy with the regime, promised to install 'freedom of meeting, free press, belief and its exercise' ${ }^{38}$ Religious organizations, including the newly-organized AMC, capitalized on the lifting of religious bans to mobilize further support for the liberalization of religious freedom and activity. The first pluralist parliament elected in 1991 made sure to replace the atheist proviso with a liberal clause: 'the state respects religious freedoms and creates the conditions for their exercise.$^{39}$ In 1993, the newly-elected DP majority opted for an even more permissive and elaborate proviso: 'The right of thinking, conscience and faith are inviolable. Everyone is free to change religion and beliefs and express them individually or collectively'. ${ }^{40}$ Country's legal framework, however, fell short of specifying how to enable and restrict the rights in question and what was the role of the state in the process. The formal regulation of religious activities took almost another decade to complete. 
Given the lack of a proper legal framework, the relations between the state and religious communities, particularly the larger Islamic community, settled on an ad hoc and mutuallybeneficial modus vivendi for both. After its election in 1992, the DP majority proffered a number of different incentives to mobilize the support of the Muslim majority for its governing project. The clergy and believers in general were seen as a former dissident pool almost naturally inclined to support the DP's anti-Communist agenda. That some Muslim-majority strongholds in Central and Northern Albania, such as Shkodra and Kavaja, suffered particular deprivation during the Communist regime, strengthened the DP's political grip on these parts of the country. ${ }^{41}$ Core DP leaders capitalized on the existing religious and regional frustrations, but pursued preferential links with the Muslim community, probably because of its sheer size. To start with, soon after the 1992 elections, the DP majority nominated an AMC representative to chair the State Secretariat (SS), the only state institution in charge of administering religious affairs. Handing the SS's chairmanship to the AMC signalled a certain preference for the Islamic majority, and gave the organization an actual institutional role to shape state policies concerning religion. The vague organization and competences of the SS, moreover, allowed the chair to intermingle 'religious interests' with 'state functions', and 'exceed its competences. ${ }^{42}$ In parallel, important DP politicians, including the chair of the then security services, Bashkim Gazidede, piloted the creation of Kultura Islame (KI), a semi-formal organization which maintained links between party structures, Sunni hierarchy and foreign charities willing to finance the revival of Islam. $^{43}$

The DP leading authorities also made no secret of their intention to use the brand of Islamicmajority in order to garner much-needed economic and political capital from the wider Muslim world. The DP chair and then newly-elected president, Sali Berisha, forwarded a letter to then Prime Minister Alexander Mexi, advising him that the country's inherited poverty could only be eradicated through foreign aid, including aid from Islamic countries. ${ }^{44}$ Since aid from Western countries failed to arrive, the government focused on attracting potential donors from the Islamic world. A 1992 Presidential Decree that made Albania full member of the Organization of Islamic Conference (OIC) served to intensify institutional links with the universe of Muslim donors and investors. The OIC membership certainly created new opportunities for Islamic charities, 
including cash-rich Saudi investors, to arrive in the country with hefty investments for the economy alongside the regeneration of Islam. ${ }^{45} \mathrm{KI}$, which was led by a government official, Gazidede, facilitated Muslim investors' access to governing authorities. The lifting of visa requirements for all OIC citizens further facilitated the entry of Muslim missionaries and networks. Some of the arriving missionaries even enjoyed an expedited process of Albanian citizenship given their links with KI and its chair Gazidede, who was also in charge of the final approval of applications for citizenship.

The central Sunni hierarchy seized the opportunities offered by external funding and networking in order to regenerate the role of Islam. As the first Chair of the AMC noted, 'the democratic victory of 1990s has created new chances [for the AMC] to connect with the world, develop new thinking, renew attempts to strengthen faith and discover religious morality'. ${ }^{46}$ It was during this period of legal vacuum that the AMC proliferated its connections with foreign organizations, rebuilt its basic infrastructure, established an entire system of education, proliferated its publications, and jump-started a range of social and humanitarian activities mixed with proselytization activities. ${ }^{47}$ The recovery of the AMC's activities, at least initially, was almost entirely dependent on foreign networks and funds willing to finance the revival of Islam. Owing to its formal and informal ties with government authorities, the AMC had carte blanche to develop its links, reorganize its structure and cultivate new activities at will.

The lack of mechanisms for registration, screening, and surveillance of the surging religious activities, when coupled with government's underground links with Muslim networks, opened the country to all kinds of Islamic missionaries, ideas and agendas. Competition for 'the hearts and minds' of post-atheist Albanian souls was especially fierce given country's closeness to European borders. To paraphrase an observation of that period, 'when the Communist law was swept aside, but no new legal framework was put in place, Albania was invaded once again: by business prospectors, "advisors", observers and religious groups who came to recruit for their faiths ${ }^{48}$ At the time, Arab foundations had arguably projected a three-stage plan of Islamization: 1) initial financial assistance would lead to 2) the promotion of 'pure' Islamic values, which would then lead to 3) the installation of an Albanian Islamic state. ${ }^{49}$ In tune with this plan, the lion's share of Arab organizations' assistance focused on converting Albanians to 'pure' Islamic 
behaviours. ${ }^{50}$ The creation of a new ulama instructed in leading centers of Islamic theology that could help to 'coach' lay believers was at the very core of the project. Hundreds of Albanians were given scholarships to study theology abroad. Quran courses proliferated, and diverse Islamic periodicals and translations became available for free. ${ }^{51}$ One of the Arab foundations alone distributed 3 million copies of the Quran, more than the total size of country's population, in the period between 1992 and 1994.

By 1998, it was clear that the laissez faire approach and the resulting modus vivendi between governing authorities and the mushrooming Muslim actors represented a fragile basis for the state supervision of religious activities. Foreign reports demonstrated that various Islamic 'charities' had been able to employ political links in order to develop illegal activities and establish terrorist cells in the country; activities that thrived during the collapse of the government and the socio-political turmoil that followed in the period 1997-1998. ${ }^{52}$ The ruling elite, meanwhile, proved ready to use the card of pan-Islamism against the West as soon as key European countries came to criticize government's authoritarian turn and Berisha's consolidation of a one-man rule. As Berisha himself explained in an interview with the Iranian public television questioning about the source of protests engulfing the country in 1996:

The situation is a perfect example of Great Powers' treatment of 'Islamic extremism' as an alibi to advancing their respective imperialist goals. We are speaking about the same authors, i.e. to say those that led the war in Bosnia. No one knows what Great Powers are cooking in this country. But, as an Egyptian thinker who wrote the introduction of the Albanian translation of Quran predicted, Albanian Muslims face a bleak situation in Europe. $^{53}$

While Albanian's office-holders might not have been terribly serious about the option of an allIslamic fraternity or the propagated anti-Western zeal, the open state policies towards incoming Islamic organizations and charities placed the country in the list of those providing 'a safe and undisturbed refuge for Islamic terrorists' ${ }^{54}$

The Formalization of Religious Restrictions and State Supervision 
The threat of foreign and home-grown terrorist movements triggered a period of soul-searching amongst Albanian elites and Muslim hierarchy for most suitable regulatory policies towards mushrooming religious activities. The incoming Socialist Party (SP), which won the fresh 1997 elections, initiated a systematic scrutiny of the Islamic 'charities', formally or informally related to former DP ruling structures. In close collaboration with the FBI and European anti-terrorist agencies, the new authorities implemented some exceptional security measures. The campaign ended with the incarceration of a group of suspected terrorists, the closure of the most active Arab foundations, and the expulsion of related personnel in 1998. New waves of arrests and expatriation continued after 9/11, and also after the killing of an AMC official, allegedly by radicalized Muslim activists in 2004. Contacts with the Islamic 'world' were similarly restricted to indispensable bilateral relations with a few selected countries.

The governing authorities also initiated the formalization of a proper regulatory framework regarding the rights and restrictions of religious communities, and their relationship to the state. The 1998 Constitution elaborated in particular detail the terms for the separation, control of, and collaboration between the state and religious organizations. ${ }^{55}$ At the base of the new framework were the principles of religious freedom, state neutrality and mutual collaboration between the state and churches towards a 'common good'. Accordingly, the state has no official religion, but respects the equality of all religious communities; the two enjoy 'mutual independence' but are still required to 'work together for the good of each and all. ${ }^{56}$ The state, moreover, is attributed a key role in defining and protecting the 'good of each and all', when safeguarding that religious rights 'do not infringe upon the interests' of 'third parties'. State's supervisory role is embedded in institutional procedures for the registration of religious organizations. The 1998 Constitution awards religious organizations the status of 'judicial personality'. The 2001 Non-profit Organizations Law specifies that religious organizations should 'earn' this status by registering with the Court of Tirana; a process that automatically scrutinizes related organizations for compatibility with the state's legislation. In line with new state's role, the statutes of the Committee of Cults, the successor of the SS, also prescribe that the committee should be chaired by a neutral civil servant representing the state. ${ }^{57}$ 
The new legal framework makes sure to accord special privileges to the so-called traditional communities - Sunni, Bektashi, Catholic and Orthodox Christian - which in fact facilitates state's collaboration with and its supervision of religious activities. Specifically, traditional communities, each represented by one formal central organization, are entitled to negotiate bilateral agreements that regulate the particular details of their relationship with the state. The agreements provide a legal opportunity to pin down the mutual commitments of the state and respective community, but also single out the religious interlocutors who can collaborate with the state authorities. $^{58}$

The AMC, since its creation in 1991, followed the model of representative functions of the nationalized religious hierarchy first created in 1923. Founded by a group of imams, with links to the pre-Communist structures, the association claimed nationwide authority in the administration of all affairs pertinent to the Muslim community. Its 1993 Statute envisaged a tightly centralized managerial umbrella operating under the Head of the AMC and an Executive Board close to him. The statute also formalized the role of the AMC as 'the only authority' responsible for the management of Muslim endowments, the maintenance of related infrastructure, the organization of religious education, and the representation of Muslim believers in relevant public activities. The central structure controls and instructs a net of local branches, organized according to the administrative divisions of the country. ${ }^{59}$

This tightly-centralized and hierarchical model of organization, however, did not fit in well with the decentralized flow of external funding and networks that permeated the country in the early 1990s. Many of the foreign built mosques, for example, remained de facto under the control of the associations that financed their construction. Foreign-funded Islamic education, publications, periodicals, and social activities remained also under the influence if not the control of respective sponsors. ${ }^{60}$ This bifurcation between the AMC's formal monopoly in the management of Muslim affairs and decentralized actual sources of funding became the main target of the new legal changes. The post-1998 regulatory framework endorsed the role of the AMC as the only authority that can engage in direct negotiations with state institutions, be represented in the Committee of Cults, enjoy free access to state media and benefit from state funds, making it the only official organization 'representing' the community. ${ }^{61}$ 
The incoming legal restrictions sent ripples of change throughout the structures of AMC. The subsequent 2002 and 2005 statutes centralized even more authority around the office of the Chief Mufti and executive organs close to him. ${ }^{62}$ The 2005 Statute specifically required imams to pledge an oath of allegiance to 'the legislation of the Republic of Albania' before taking up the job. ${ }^{63}$ The 2009 bilateral agreement between the state and the AMC, then elaborated the ties between the state and the community, especially on issues of 'common concern' such as the goals of democracy and European integration. Specifically the state pledged to protect the AMC 'against any deformations, extremist tendencies, or other aggressive demonstrations in the spaces occupied by [its] believers'. ${ }^{64}$ The Sunni hierarchy, in return, vowed to respect state guidelines for the protection of 'a democratic society, public security and third-party rights'. 65

\section{The Benefit of Tradition}

The choice to reshuffle the relation between the state and the Muslim community along the lines of a local interpretation of laïcité, seemed to amass the consensus of a broad coalition of actors mainstream intellectuals, ruling elites and the Sunni establishment. It is this coalition working under the backing of the state, which helped to legitimize and perpetuate the model. ${ }^{66}$ That the institutional templates replicated some of the founding solutions to accommodate Islam, religious plurality and European statehood increased the appeal of the model. Indeed, the historical templates that served to glue together the post-Ottoman unitary modern and European Albanian polity provided useful sources for re-envisaging church-state relations in the post-Communist era.

Albanian intellectuals, often educated during decades of Communist propaganda, continued to construe images of Islam as a knotty religion that requires state supervision and conjectural reform in order to fit country's aspirations towards democracy and European integration. Replicating some of the debates of the past, Islam was frequently portrayed as a remnant of the Ottoman era, which impeded country's return to the 'the family' of European democratic states. ${ }^{67}$ Ismail Kadare, a celebrated literary authority, for example, speaks on behalf of many intellectual vanguards when suggesting that, 'the Albanian path towards Europe should be taken 
without the baggage of Islam, which is not worth it, and only delays the arrival' ${ }^{68}$ Many semiliterary works similarly sketch Islam with dark, anti-European overtones -barbaric, violent, immoral, and traitors of Christianity - and certainly a stranger to the united Europe in which Albania wants to partake. ${ }^{69}$ The recommended solution, similar to the pre-Communist era, is a locally-trimmed reformist version of the creed, which adheres to the country's tradition and promulgates new political goals of democratization and European integration.

Such interpretations of Islam that follow the historical tradition and political goals are condoned, if not advanced, by ruling political elites. When Albania was nominated as a candidate country for EU membership in 2014, the Prime Minister, Edi Rama, made clear the country’s irrevocable choice for Europe, and where Muslims fit in: 'This is not a Muslim, but a European country. Not only Albania, but Albanian people have always been and remain believers of Europe. ${ }^{70} \mathrm{~A}$ few years earlier, then president Alexander Moisiu articulated this juxtaposition in sharper tones: 'Albanians are often cited as ... a country of Muslim majority. [But] this is a very superficial reading of the reality... Islam in Albania is neither a residential religion, nor a faith spread originally.... As a rule, it is a shallow religion'. ${ }^{71}$ The intrusion of terrorist movements and the spread of anti-terrorist rhetoric since 2001 have increasingly shifted attention towards the virtues of local tradition. ${ }^{72}$ In the context of terrorist-ridden debates, political elites were careful to remind Muslims of their duty to adhere to the Albanian-specific tradition and end goals of national unity and European modernity. In the evolving discourse, moreover, central organizations were trusted with the role of upholding past traditions: 'These days when the Albanian society faces many challenges, we need to bring to the fore more than ever our national solidarity and soul. I am sure that [central] religious organizations will contribute to carry on our traditional principles of love and tolerance. ${ }^{73}$ Transmitting the past reformist templates into the new post-Communist context, moreover, is considered 'a mission toward [the country's] European dream'.74

The AMC, as the official interlocutor which operates at the interface between the state and the community, has certainly taken the lead in spelling and carrying out the local-specific traditional templates. Soon after the adoption of the new regulatory framework, the AMC moved to reshuffle its organigram with authorities who toed the traditional line. Haxhi Selim Muca, the 
Chair of AMC in the period 2004-2014, expounded a 'fresh' vision for the community: improved image, independent finances, modern publications, updated curricula, and rejuvenated staff. ${ }^{75}$ The organization also self-defined itself as a guardian of 'Albania[n] culture, tradition and social characteristics. ${ }^{76}$ If there was any doubt about the role of AMC, the state authorities made use of all possible channels to remind AMC officials of the benefits of the traditional choices for Albania's pluralist society: 'From its very birth, the Albanian state has embraced laicity as a formula that incorporates the interests of all Albanians and their common ideal of coexistence. Laïcité is a necessary condition for harmony in multi-religious societies like ours' ${ }^{77}$ In this model, moreover, official hierarchies are to collaborate with the state: 'state and religion, are close partners in our path towards progress and realization of our objectives. Religious organizations serve our national advancement because they cultivate via faith values that the state promotes via reason., 78

Not all newborn Muslim groups that thrive in the autonomous spaces of civil society agree with the dimensions of the Albanian version of laïcité, the traditional templates, or the collaboration between the AMC and the state. Decentralized groups of believers avail of alternative channels in order to learn and discover their religion. Lay believers have Internet access, read international publications, study abroad, make pilgrimages, attend conferences, follow online sermons and fatwas, and organize informal meetings. ${ }^{79}$ In this open and competitive market of ideas, Islamic religiosities are typically more personal, less institutionalized, and detached from the traditional historical prescriptions as much as the organized religious hierarchy. As Endresen puts it, 'the general situation is one of conflict over sacred authority, fragmentation of interpretations, and new, emerging forms of religiosity. ${ }^{80}$ At least some of these groups believe that 'Muslim behavior must always be governed by knowledge and rules based on sacred scripture, not on culture and tradition', 81

The all-powerful alliance between intellectuals oriented towards European models, governing elites committed to the project of EU integration, and a politically-engaged Muslim hierarchy, however, overrate alternative preferences or solutions that might thrive at the core of Islamic civil society. Post-Communist citizens, including a critical mass of lay Muslims, on the other hand, seem keen to protect their democratic rights and rally around familiar traditional templates. 
Survey data show that most post-Communist Albanians opt for individualized 'pick and choose' modes of religious practice - only 5\% attend religious services weekly; $50 \%$ attend religious ceremonies only during poignant moments in life such as birth, marriage and death; and the majority supports institutional arrangements that confine religion strictly within the private realm

- away from schools, public spaces and state institutions in general. ${ }^{82}$ Indeed, the alliance between mainstream intellectuals, governing elites, religious hierarchies and secularized citizens hold the reigns of the direction of Islam along the inherited templates of the past and their recasting according to socio-political priorities of the present.

\section{Conclusions}

This article analyzed the institutional regulations to managing Islam in post-Communist Albania. The empirical examination focused on the range of institutional devices that mark Albanianspecific interpretations of laïcité, how they built upon past solutions, but also how they changed and developed across the socio-political contingencies of time and place.

The analysis demonstrates that the state's initial laissez faire approach towards religion ushered in a period of soul-searching for appropriate models to regulate the booming Islamic activities and competing religious networks and agendas. The revised institutional arrangements enshrined state neutrality alongside ample religious freedom, but also a set of restrictions and tighter collaboration between the state and Muslim hierarchies for the purpose of advancing 'the common good'. The fortification of a Muslim hierarchy, which plays the role of interlocutor between the state and the community, is at the core of the Albanian version of laïcité. These devices ultimately aim at safeguarding a local reformist version of Islam, which builds on past templates and develops in line with political priorities - democracy and European integration.

That the model replicated some of the choices that served to glue together the Muslim majority and multi-denominational Albanian polity into an independent nation-state endowed it with legitimacy and resilience. A broad coalition of Albanian actors including mainstream intellectuals, governing elites, and the Muslim hierarchy rallied around the benefits of traditional 
choices. The pool of institutional and ideological solutions that succeeded in reconciling Islam, religious plurality and European statehood in the past proved useful in re-envisaging the state's relations with the Muslim community also in the post-Communist context.

Our findings corroborate a broader research agenda highlighting that various socio-political contexts lend themselves to different models of secularism. Hence, secularism, including the French ideal of laïcité, is not a global and uniform concept or practice. Instead it takes different forms depending on the context and socio-political contingencies of time and place. The liberal presumption of a hands-off 'wall of separation' between church and state, and the implication of state indifference to religious activities, moreover, means little in complex plural societies that face the need to arbiter and regulate competing 'truths'. The case of Albania suggests that the realization of religious freedom and equality requires the active involvement of the state as a referee engaged in interpreting and applying impartial rules of the game between different contenders with alternative visions of 'good life'. State involvement requires a certain separation, but also cooperation with and control of religious actors in order to ensure common goods: religious peace, practice of belief, and ultimately citizens' identification with the state as a plural 'home for all'.

\section{Acknowledgements:}

The authors are grateful for financial support to Robert Schuman Centre for Advanced Studies, (RSCAS), ReligioWest Project, and European Research Council (ERC grant agreement no 269860).

\section{Notes on contributors}

Arolda Elbasani is a visiting fellow at the Robert Schuman Center for Advanced Studies. Her research interests and publications lay at the intersection of European integration, comparative democratization, Islamic politics and state-church relations. 
Artan Puto is Professor of History and Nationalism at University of Tirana. His work focuses on theories of nationalism, Ottoman Empire and intellectual history with a focus on the Balkans. He is co-editor of Perpjekja, a quarterly cultural and literary magazine published in Tirana.

\section{Notes}

${ }^{1}$ According to the most recent 2011 census, the shares of religious denominations are: $57.12 \%$ Sunni Muslims, 10.11\% Catholic, 6.8\% Orthodox, 2.11\% Bektashi, 0.11\% Evangelist. Around $2.5 \%$ declare themselves atheists.

${ }^{2}$ R. M. Della Rocca, Nation and Faith in Albania, 1920-1944, Elena Gjika, Tiranë, 1994 [in Albanian].

${ }^{3}$ The formal use of the Albanian term shtet laik, and first institutional attempts to operationalize the concept, go back to the period of foreign-supervised independent statehood in 1914. Since then, public debates, intellectual propositions and political reforms have embraced the changing idea and visions on what constitute a laic state.

${ }^{4} \mathrm{~T}$. Bamir, Greetings of President Topi in the Ceremony of Decoration of Four Highest Spiritual Leaders of Albanian Religious Communities, 5 April 2010 [in Albanian].

${ }^{5}$ The AMC is the central organization, which is officially recognized as the representative organization of the Sunni community. The function and competences of AMC in relation to the broad 'community' have changed over time. So, have its relations to the state authorities and privileges granted. We focus on the changing organizational functions of the AMC and its relation to political authority as a crucial aspect of the local solutions of laïcité.

${ }^{6}$ A. George, and A. Bennett, Case Studies and Theory Developments in Social Sciences, MIT Press, Cambridge, 2005, 205-32.

${ }^{7}$ A. Elbasani, 'Governing Islam in plural societies: religious freedom, state neutrality and traditional heritage', Journal of Balkan and Near Eastern Studies, 2016.

${ }^{8}$ C. Endresen, Is the Albanian's Religion Really 'Albanianism'? Religion and Nation According to Muslim and Christian Leaders in Albania, Harrassowitz Verlag, Wiesbaden, 2012, p. 54.

${ }^{9}$ N. Clayer, Aux origines du nationalisme albanais. La naissance d'une nation majoritairemet musulmane en Europe, Karthala, Paris, 2007, pp. 24-25.

${ }^{10}$ S. Frashëri, 'Albania - what it was, what it is and what it will be,' Rilindja (2) Prishtinë, 1978, p. 61.

${ }^{11} \mathrm{G}$. Duijzings, Religion and the Politics of Identity in Kosovo, Hurst and Company, London, 2000, p. 161.

${ }^{12}$ Quoted in Ibid., p. 103.

${ }^{13} \mathrm{~N}$. Clayer, Aux origines du nationalism, op.cit., pp. 272-84; A. Puto, The Idea of the Nation During The Albanian National Movement, 1878-1912, PHD thesis, European University Institute, Florence, 2010, pp. 169-71.

${ }^{14}$ E. Sulstarova, Escaping East: Albanian Orientalism from Naim to Kadare, Botimet Dudaj, Tiranë, 2006, pp. 36-60 [in Albanian].

${ }^{15}$ A. Elbasani and M. Somer, 'Muslim Secularisms in the European Context', In M. Rechtenwald et. al. (eds), Global Secularisms in a Post-Secular Age, De Gruyter, Boston, 2015, pp. 171-189. 
${ }^{16}$ Artan Puto, The Idea of the Nation, op.cit., p.183.

${ }^{17}$ The Organic Statute of Albania, chapter III, article 32; chapter XI-article 170, http://shtetiweb.org/wp-content/uploads/2012/10/STATUTI-ORGANIK-I-SHQIPËRISË.pdf (accessed on 15 June 2015).

${ }^{18}$ Ibid., chapter IV, article 41, 42.

19 Ibid., chapter XI-article 176.

${ }^{20}$ A. Puto, Political Albania, 1912-1939, Botimet Toena, Tiranë, 2009, pp. 298-9 [In Albanian].

${ }^{21}$ L. Skendo, Knowledge, Shtëpia e Librit, Tiranë, 1999, p. 427 [in Albanian].

${ }^{22}$ Extension of the Statute of Lushnja, chapter II, article 93, http://shtetiweb.org/wpcontent/uploads/2012/10/Zgjerimi-i-Statutit-te-Lushnjes-1922.pdf (accessed on 15 June 2015).

${ }^{23}$ A. Popovic, L'Islam balkanique. Les musulmans du sud-est européen dans la période postottomane, Les Éditions Isis, Istanbul, 2009, p. 21; Della Rocca, Nation and Faith, op. cit. pp. 2831

${ }^{24} \mathrm{~N}$. Clayer, 'Behind the Veil. The reform of Islam in Inter-war Albania or the search for a “modern” and “European” Islam,' in N Clayer and E. Germain (eds), Islam in Inter-War Europe, Hurst, 2008, p. 148.

${ }^{25}$ The Founding Statute of the Albanian Kingdom, article 207, 1928, http://shtetiweb.org/wpcontent/uploads/2012/10/Statuti-i-Mbretnis-Shqiptare.pdf (accessed on 15 June 2015).

${ }^{26}$ A. Popovic, L'Islam balkanique, op.cit., p. 31; C. Endresen, Is the Albanian religion really "Albanianism"? op.cit., p.63.

${ }^{27}$ N. Clayer, 'Behind the Veil,' op. cit, p. 129.

${ }^{28}$ A. Popovic, L'Islam balkanique, op.cit., pp. 28-29.

29 Statuti I Komunitetit Mysliman Shqiptar, chapter 3, article 11, 1929, http://licodu.cois.it/?p=214 (accessed on 15 June 1015).

${ }^{30}$ N. Clayer and X. Bougarel, Les musulmans de l'Europe du Sud-Est. Des Empires aux États balkaniques, IISMM-Karthala, Paris, 2013, p. 126.

${ }^{31}$ Della Rocca, Kombi dhe feja në Shqipëri, op.cit., pp. 205-7.

${ }^{32}$ A. Basha, Islam in Albania throughout Centuries, Bibloteka Islame, Tirane, 2000, pp. 163-7 [in Albanian].

33 Ibid.

${ }^{34}$ P. Prifti, Socialist Albania since 1944: Domestic and Foreign Developments, MIT Press, Cambridge, 1978.

35 The People's Assembly, the Constitution of the Popular Socialist Republic of Albania, article 26, 1976, http://licodu.cois.it/?p=383 (accessed on June 2015).

${ }^{36}$ A. Elbasani, 'Islam and democracy at the fringes of Europe. The role of useful historical legacies,' Politics and Religion 8 (2), 2015, 334-357.

37 A. Elbasani, 'State-organized religion and Muslims' commitment to democracy in postCommunist Albania’, Europe-Asia Studies 2016, 10.1080/09668136.2015.1136596 Forthcoming.

${ }_{38}^{38}$ A. Krasniqi, 'Parties and religion: a relation in transition', Social Studies 8(1), 2014, p. 8.

39 People’s Assembly, Principle Constitutional Provisions, article 7, 1991, http://licodu.cois.it/?p=365 (accessed on 15 June 2015).

${ }^{40}$ People’s Assembly, Constitutional Law, article 18, 1993, http://licodu.cois.it/?p=367 (accessed on 15 June 2015).

${ }^{41}$ A. Elbasani, 'Islam and democracy', op. cit., 
${ }^{42}$ A. Elbasani, 'State-organized religion', op. cit.

${ }^{43}$ R. Lakshman-Lepain, 'Albanian Islam -Development and Disruptions,' in K. Kasser and F. Kressing (eds), Albania -A Country in Transition, Nomos Verlag, Baden Baden, 2002, pp. 3465.

44 Ibid.

${ }^{45}$ In the early 1990s, aid from Islamic countries amounted to around 90\% of the budget of AMC, $50 \%$ of foreign investment, and over 5\% of GDP, see Lakshman-Lepain, op. cit., p. 49.

${ }^{46}$ I. Dizdari, and F. Luli, F. 'Hafiz Sabri Koci Pishtar i ringjalljes Islame ne Shqiperi,' Drita Islame, 2003, p. 9 http://www.kmsh.al/al/?p=778 (accessed on 18 June 2014).

${ }^{47}$ O. Jazexhi, 'The Muslim community of Albania. From the Turkish Caliphate to the Turkish Djemat,' Paper presented in the conference: Dealing with change: Islamic leadership in the Balkans and the Baltic between past and future, Sofia, 16-18 May 2011, pp. 10-13.

48 A. Youngs, Religion and Society in Present Day Albania. Institute for European Studies: Working paper, 97/3, 1997, p. 5.

49 A. Othman, A. 'Albania begins search for the lost Islamic moorings,' Arab News, 8 December, 1993.

${ }^{50}$ Lakshman-Lepain, ‘Albanian Islam,’ op. cit., pp. 44-45.

51 M. Vickers, and J. Pettifer, J. Albania From Anarchy to a Balkan Identity, Hurst and Company, London, 2000, pp. 100-9.

52 Ibid., pp. 106-7.

${ }^{53}$ Cited in A. Puto, The Challenges of Human Rights and a Free Society, Toena, Tirana, 2015 [in Albanian]

${ }^{54}$ ICG, The State of Albania, Balkans Report No. 54, 1999, p. 7.

${ }^{55}$ For a similar account see also the post-Dayton constitutional framework in Bosnia, A. Alibašić and N. Begović, 'Reframing relations between state and religion in post-war Bosnia: learning to be free!', Journal of Balkan and Near Eastern Studies, 2016, Forthcoming.

56 The Albanian Parliament, Albanian Constitution, 1998, article 10, http://licodu.cois.it/?p=389 (accessed on 18 June 2014).

57 The Council of Ministers, Decision on the Creation of the Committee of Cults, 1999, Decision No. 459.

${ }^{58}$ A. Elbasani and O. Roy, 'Islam in the post-Communist Balkans: alternative pathways to God', Southeast European and Black Sea Studies, Online First: 10.1080/14683857.2015.1050273; A. Elbasani, 'Introduction: Nation, State and Faith in the Post-Communist Era', in A. Elbasani and O. Roy (eds), The Revival of Islam in the Balkans: From Identity to Religiosity, Basingstoke, Palgrave Macmillan, 2015, pp. 1-23.

${ }^{59}$ For a current update of the organizational structure, see http://www.kmsh.al (accessed on 18 June 2014).

${ }^{60}$ Lakshman-Lepain, ‘Albanian Islam,’ op. cit.

${ }^{61}$ A. Elbasani, 'Islam and democracy,' op. cit.,

62 AMC, The Statute of Albanian Muslim Community, 2005, http://licodu.cois.it/?p=226 (accessed on 18 June 2014).

63 Ibid., article 8, 40.

64 The Albanian Parliament, Ratification of Agreement for the Regulation of Mutual Relations between the Council of Ministers and the Albanian Muslim Community, 2009, article 3, http://licodu.cois.it/?p=118 (accessed on 18 June 2014). 
65 Ibid.

${ }^{66}$ A. Elbasani, 'State-organized religion,' op. cit.

${ }^{67}$ A. Elbasani, 'Islam and democracy,' op. cit., p.

${ }^{68}$ Quoted in E. Sulstarova, Arratisje nga Lindja, op. cit., p. 265.

${ }^{69}$ Ibid.

${ }^{70}$ E. Rama, 'Albanians believe in Europe more than in Religion,' Gazeta Tema, 28 June 2014 [In Albanian].

${ }^{71}$ A. Moisiu, A. Inter-religious Tolerance in Tradition of Albanian People, Speech held at Oxford Institute, 9 November 2005

${ }^{72}$ For a similar account in Bulgaria see E. Ivanova, Islam, 'State and society in Bulgaria: religious freedoms and the weight of tradition', Journal of Balkan and Near Eastern Studies, 2016, Forthcoming.

${ }^{73}$ B. Nishani, 'Nishani-Brucaj, let us diffuse the positive values of Islamic faith,' Gazeta Shqiptare, 18 Mach 2014 [In Albanian]

${ }^{74} \mathrm{~B}$. Nishani, 'In the 90s anniversary of AMC: religious tolerance, cultural patrimony,' Shekulli, 11 March 2013 [In Albanian].

75 AMC, Kryetari, 2012, http://www.kmsh.al/al/?page_id=17, (accessed on 18 June 2014).

76 AMC, University Full Moon - BEDËR, 2013, http://www.kmsh.al/al/?page_id=33(accessed on 18 June 2014).

${ }^{77}$ B. Topi, Speech held at the Conference The Contribution of Religious Harmony in Processes of Integration, Tirana, 2 April, 2010.

${ }^{78}$ Ibid.

79 A. Elbasani, and O. Roy, (eds) The Revival of Islam in the Balkans: From Identity to Religiosity, Palgrave, London, 2015.

${ }^{80}$ C. Endresen, 'Faith, Fatherland, or Both? Accommodationist and Neo-Fundamentalist Islamic Discourses in Albania,' in: A. Elbasani, A and O. Roy (eds) The Revival of Islam in the Balkans: From Identity to Religiosity, Palgrave, London, 2015.

${ }^{81}$ Ibid.

${ }^{82}$ University of Oslo, Survey on Strategies of symbolic nation-building in West Balkan states intents and results, 2013, http://www.hf.uio.no/ilos/english/research/projects/nation-w-balkan/ 